\title{
ASPECT AND AKTIONSART OF SECONDARY ASPECTUAL VERBS IN SERBIAN
}

The aim of the paper is to investigate aspectual value of secondary aspectual verb phrase in Serbian in terms of both grammatical and lexical aspect (Aktionsart). The present analysis focuses on two secondary aspectualizers krenuti and stati, which when used as lexical verbs have the opposite meanings related to motion in space, but when they appear as phase construction heads both verbs modify the opening segment of the aspectual event. The central idea of the proposal is that event types in general largely depend on temporal structures which need to be contextualized before they are formally identifiable. In other words, contrary to traditional approaches which define lexical aspect as inherent to verb meaning, we claim that each verb form (or any lexical and/or grammatical form for that matter) has an underlying meaning through which it entertains systematic relations with other forms in a language (Hirtle 1982:40). We start from aspectual and Aktionsart features of krenuti and stati as verb lexemes, then move onto the level of syntax to identify the cocompositional aspect of the overall phase construction via event structure and event segmentation mechanisms. Finally, the present paper aims to examine different uses of the two secondary aspectual verbs, along with the different types of events they can denote in order to bring to light the potential meanings which give rise to the various contextual senses of the aspectual construction. The reported results of the analysis were checked on the Corpus of Contemporary Serbian Language (SrpKor 2013).

Key words: aspectual constructions, Aktionsart, aspectual event, temporal structure, secondary aspectualizer, event segmentation, event co-composition

\section{INTRODUCTION}

The paper deals with the aspectual value and Aktionsart features of two antonymic Serbian secondary aspectualizers krenuti ( "start") and stati ( "stop"), both inside and outside the aspectual phrase in which they surface as head verbs. Generally speaking, aspectualizers (also phase or aspectual verbs) are complement-

\footnotetext{
*natasa.milivojevic@ff.uns.ac.rs
} 
taking verb heads which denote the initiation, termination, or continuation of an event (Antonić, 2000; Brinton, 1985, 1988; Comrie, 1976, 2004; Dowty, 1977; Freed, 1979; Ivić, 1961, 1983; Levin 1993; Milivojević, 2021a, 2021b, 2021c; Mrazović\&Vukadinović, 1990; Nagy，2009，2016; Newmeyer，1975; Novakov 2005; Palmer, 2009; Perlmutter, 1970; Piper et al., 2005; Pustejovsky, 1995 among others). As Milivojević (2021c:31) points out "aspectual verbs describe some kind of the temporal condition resulting from the temporal structure of an event which is, in turn, additionally determined by the aspectual interaction between the head verb and its complement. The meaning expressed by the aspectualizers and their complements is therefore understood as semantic co-composition ${ }^{12}$ resulting at the level of the aspectual construction as a whole." When it comes to secondary aspectual verbs in Serbian, Piper (Piper et al. 2005:313) and Author (2021a:198202) propose a subclass of secondary (atypical) aspectualizers to the class of Serbian aspectual verbs: these verbs are primarily lexical verbs which yield an aspectual meaning when combined with an aspectual complement. ${ }^{3}$

The key theoretical idea which underlines the present proposal is that verbs, as time-event denoting class, can be differentiated according to how the denoted events happen and/or take place in time (cf. Freed, 1979; Levin, 1993, 2000; Nagy, 2009, 2016; Rothstein, 2004; Vendler 1957 among others). Furthermore, the ontological types of events are determined by their temporal structural contours. That is, Aktionsart notions of Vendlerian type such as duration, momentariness, segmentation, event viewed as a structure, event viewed as a whole, and the like are critical to structuring lexical semantic representation. In terms of temporal structure, we adopt Freed's (Freed, 1979) view of aspectual event structure. Freed introduces a specified temporal structure of a prototypical aspectual event that may consist of three segments: onset, nucleus and coda. However, not all events possess the full range of segments. The onset of the event is a temporal segment which takes place before the initial temporal part of the nucleus of that event. More precisely, the onset is the preparatory stage necessary before the core, or the nucleus activity which is being initiated. During the nucleus, the event is in progress. After the final

\footnotetext{
${ }^{1}$ The term is used in the sense of the Generative Lexicon (Pustejovsky, 1995).

2 According to Milivojević (2016: 59) "co-composition is the process of mapping meaning onto structure whereby the head and the complement influence each other through a number of typeshift and coercion operations."

${ }^{3}$ The subclass of secondary aspectualizers is constituted of three verbs krenuti, uzeti and stati. For detailed discussion see Piper et.al. 2005 and Milivojević 2021a-c.
} 
stage of the nucleus, the nucleus of the entire event is over. Certain types of events which are not considered completed even after the end of the nucleus have the final segment which is defined as coda. ${ }^{4}$

The central focus of the present research is on two secondary aspectual verbs in Serbian, krenuti and stati. These two verbs belong to a subset of Serbian aspectual verbs. According to Milivojević:

Phase (aspectual) verbs are assumed to be a part of a decomposed predicate, alongside copulas, semi-copulas and modal verbs... these verbs take up complements of a defined and restricted range of syntactic types (da+present clause, gerund, infinitive, noun phrase) ... Alongside typical phase verbs in Serbian such as početi, nastaviti, prestati, there is an onset of verbs which are not primarily treated as aspectualizers but may be used in the aspectual sense. In such cases they behave as aspectualizers within the relevant linguistic context. Such verbs are krenuti, uzeti i stati: Ona krenu/uze/stade plakati//Oni krenuše/uzeše/stadoše da se svađaju. (Milivojević, 2021b: 206)

The reasons for focusing on the verbs krenuti and stati are multiple in nature:

a) Out of the secondary aspectual subset of verbs in Serbian, only krenuti and stati denote motion in space

b) The two verbs are lexically direct antonyms, but are aspectually synonymous

c) Both verbs are additionally marked as dynamic and causative ${ }^{5}$

d) Both krenuti and stati influence their complements in terms of aspect and Aktionsart via primary lexical meaning (lexical root).

Verbs krenuti and stati are analyzed both as separate verb lexemes and as aspectual heads in a construction, i.e. outside and inside of the aspectual VP with the aim of a detailed account of the relevant lexical and semantic features which determine their aspectual behavior in the language system. Next, we turn to examine the conditions

\footnotetext{
${ }^{4} \mathrm{~A}$ coda is not always mentioned, since it is not as a rule relevant for the completion of every/any an event.
}

${ }^{5}$ For a detailed discussion see Duffley, 1999, 2006 and Author, 2021a, 2021b, 2021c. 
for the formal differentiation of the relevant lexical and aspectual denotations of Serbian secondary aspectualizers krenuti and stati.

\section{KRENUTI AND STATI AS LEXICAL AND ASPECTUAL VERBS}

As was pointed out in the previous discussion, Serbian verbs krenuti and stati may be used as full lexical verbs. In such cases they denote motion in space, or more precisely the opposing segments of the potentially identical motion event: while krenuti denotes the opening, initiation or the beginning of an event, stati denotes its stopping or termination. Therefore, in terms of their lexical denotation, krenuti and stati are antonyms. However, when the two verbs are used as aspectualizers, they become aspectual synonyms, since they both modify the initial segment or the beginning of the aspectual event. Reflecting back on Freed's (Freed, 1979) event segmentation theory, it should be pointed out that aspectual krenuti has the ability to modify both the onset and the nucleus of the aspectual event named in the complement, while stati can only refer to its nucleus. ${ }^{6}$ Furthermore, apart from its lexical and aspectual denotation, krenuti can express a range of modal and modal-like meanings which may also be contaminated by motion and/or phase. The fact that krenuti has the ability to express modal alongside with aspectual meanings is especially relevant for determining the aspectual value of the secondary aspectual constructions. We come back to this issue in section 3 .

Table 1 below summarizes the denotations of the verbs krenuti and stati according to RSKJ Rečnik Matice srpske I-VI: Rečnik srpskohrvatskoga književnog jezika (RSKJ):

\begin{tabular}{|c|c|c|}
\hline $\begin{array}{l}\text { Verb } \\
\text { lexeme }\end{array}$ & Lexical meaning & Aspectual meaning \\
\hline $\begin{array}{l}\text { K } \\
\text { RENUTI } \\
\end{array}$ & $\begin{array}{l}\text { Put into motion/ cmaвити y } \\
\text { nокрет (...) }\end{array}$ & Begin, start/ nочети, започети \\
\hline ATI & $\begin{array}{l}\text { (1) stop;(2) stand/ } \\
\text { (1) zaustaviti se, ne ići dalje; } \\
\text { (2) поставити се на ноге, y } \\
\text { cmojeћи став }\end{array}$ & $\begin{array}{l}\text { Begin/ почети, } \\
\text { настати, почети } \\
\text { с нечим (...) }\end{array}$ \\
\hline
\end{tabular}

Table 1: Denotations of the verbs krenuti and stati according to RSKJ

\footnotetext{
${ }^{6}$ Stati as an aspectual verbs generally exhibits the same lexical-syntactic behaviour as the primary aspectual verb početi, while krenuti has a range of separate, specific denotations some of which coincide with aspectual početi, while others part from it. For a detailed discussion see Milivojević (2021a, 2021b, 2021c).
} 
Examples (1) to (8) from the corpus illustrate the possible lexical and aspectual actualized, contextual denotations of the verbs krenuti and stati; examples (1) - (2) are instances of lexical krenuti, while examples (5) - (6) contextualize stati as a lexical verb. Examples (3) - (4) and (7) - (8) illustrate aspectual uses of krenuti and stati, respectively:

1. Uhvativši štap obema rukama, Franc Tajbl ga je zabio svom svojom slabašnom snagom u zemlju i krenuo dalje. Pred kućom je dugo stajao da povrati dah i da se uredi pre nego što uđe. (SrpKor 2013: Popović, Miroslav. Sudbine. Beograd : Dereta, 1994.)

2. Čim je kamion, uz glasno brundanje, ponovo krenuo, dve prilike podigle su se iz ležećeg položaja, razmenile poglede i oprezno se nasmešile (SrpKor 2013: Arsenijević, Vladimir. Predator. Beograd : Samizdat, 2008)

3. Međutim, kafu nije ni stigao da popije jer je ubrzo počela pucnjava zbog čega je krenuo da beži ka izlaznim vratima, ali ga pogađa metak i on pada, mada ipak uspeva da dođe do izlaznih vrata (SrpKor 2013: Politika, 22.08.2000.)

4. A ja sam već očeličen u bici za opstanak krenuo da igram hokej u „Crvenoj zvezdi,, i da skijam. Dogurao sam do prvog tima. (SrpKor 2013: NIN : Nedeljne informativne novine, 29. april 2002)

5. Opet je škripnuo orman. Tišina Napravio je nekoliko koraka i stao . Dugo je stajao na jednom mestu, pa je ponovo krenuo (SrpKor 2013: Blagojević, Boba. Sve zveri sto su sa tobom. Beograd : Nolit, 1975)

6. Posao na projektu je potpuno stao . Glavna briga dvojice istraživača bila je kako da sačuvaju u životu još nerođeno Pikasovo i Anino dete (SrpKor 2013: Savić, Milisav. Odbrana varoši od veštica. u: Ujak naše varoši, Beograd )

7. ...U početku osetio neku zaglušnu grmljavinu u ušima, u kojima mi je posle onaj presecani vazduh stao fijukati, zviždati, zujati, i tako besno cičati da sam mislio : ogluveću . (SrpKor 2013: Vasić, Dragiša. Vitlo. U: Antologija srpskih pripovedača XIX i XX veka; Beograd : Filip Višnjić, 1999. )

8. ... ni pogledao nije, nego je iz džepa izvukao parče ječmenog hleba i tvrdog normandijskog sira i stao da jede svoj ručak. (SrpKor 2013: Pekić, 
Borislav. Čovek koji je jeo smrt 1793.U: Antologija srpskih pripovedača XIX i XX veka; Beograd : Filip Višnjić, 1999.) ${ }^{7}$

\section{ASPECTUAL VALUE OF THE SECONDARY ASPECTUAL VP}

Aspectual verb phrase in Serbian has the structure of analytical (or decomposed) predicate (Piper et.al 2005: 312). Milivojević (2021b: 205-206) points out that in Serbian, phase verbs are generally "assumed to be a part of a decomposed predicate, alongside copulas, semi-copulas and modal verbs which may be found in the same syntactic position as an aspectualizer". According to Antonić (2000: 95-96), such decomposed VPs are on the level of syntax considered as functionally unanimous but as formally complex, since the aspectual verb has the role of a modifier in relation to the lexical verb in the complement. The same author then goes on to conclude that the phase realization of predication can be realized if and only if its denotation carries the feature [+ duration]; that is to say phase predications are durative in their default interpretations. A similar claim is also proposed by Hirtle (1988: 88) who states that any aspectual event "is represented with a beginning, a middle and an end, because the infinitesimally small (segment) can be represented only by means of a positive quantity. The point here is that we cannot represent an event without some duration, some event time".

Another widely accepted theoretical assumption in Serbian studies on aspect is that aspectual modifiers as a rule project complements with imperfective lexical verbs (cf. Antonić, 2000; Ivić, 1961, 1983; Piper et.al. 2005, among others):

9. a) Ona krenu/stade plakati.

b) Oni krenuše/stadoše da se svađaju. ${ }^{8}$

The reason for this, according to Antonic lies in the fact that Sebian aspectual verbs are marked for phase on the lexical level, i.e. they carry inherent pre-constructional meaning which then triggers an obligatory imperfective verb in the complement position. While this account is true for primary aspectual verbs, it

\footnotetext{
7 Aspectual use of stati is stylistically marked in Serbian; it mostly belongs to formal, literary register. Since the present analysis focuses only on the formal features of verbs along with their potential and actualized meanings, we leave the stylistic analysis to further research.

${ }^{8}$ The examples used in the paper are numbered throughout the text; if the source is not mentioned, they were constructed by the author for the purposes of present discussion.
} 
does not completely explain the behavior of secondary aspectualizers. Namely, secondary aspectual verbs carry traces of their lexical meaning even when they are used as semantically incomplete verbs (cf. Harley, 1999, 2010; Milivojević, 2021a, 2021b, 2021c). ${ }^{9}$ What is more, secondary aspectual verbs may be able to express additional meanings other than phase, i.e. various modal denotations, which complicates the situation on the level of the construction. The below examples (10) - (12) with krenuti binding perfective complement verbs are adopted from Milivojević (2021c: 42):

10. A Rebeke nigde. Samo slika kako se zgurila pod njegovom rukom što je bila krenula da je udari, sva trapava i pijana, sećanje na udarac pesnice o frižider. (SrpKor 2013: Grifitis, Nil. Patrljak.)

11. Odjednom se pojavio ispred mog kabineta, ispod jakne izvadio drvenu palicu i krenuo da me udari. Uspeo sam nekako da se zaštitim vratima. (SrpKor 2013: www.rts.rs (27.11.2008.))

12. A kad je voda počela da ključa i da se puši, Monmorensi je to smatrao izazovom. I baš kad bi krenuo da ga napadne, neko od nas bi mu ispred nosa odneo čajnik. Tog dana je odlučio da bude brži. (SrpKor 2013: Džerom, K. Džerom. Tri čoveka u čamcu. ASPAC.)

However, the secondary aspectualizer stati cannot be used in this way:

13. *Odjednom je stao da ga udari.

14. *Stao je/stade da ga napadne.

One possible explanation for this difference in behavior of krenuti and stati is that while krenuti has the ability to refer only to the onset segment of the aspectual event, stati, as a rule, modifies its nucleus. The same formal feature also triggers the difference in the event-cancelling condition for the two verbs: the aspectual event can be cancelled only with krenuti as the aspectual head, but not with stati:

15. Krenula je da peva, ali nije zapevala. (Milivojević 2021b: 211)

16. ${ }^{*}$ Stala je da peva, ali nije zapevala.

\footnotetext{
${ }^{9}$ See Milivojević, 2021c for a detailed account and discussion.
} 
It is important to note that in the example (16) stati has the aspectual denotation equal to that of the primary aspectualizer početi. That means that stati not only initiates, but directly modifies the nucleus of the complement event. Under such conditions, it is not possible to isolate only the opening segment (the onset) of the event and make it available for modification, hence the ungrammaticality of the example (16). Sentences with nominal aspectual complements further prove this point, since if the segmentation of the event is not possible, none of the secondary aspectualizers can be used in constructions which trigger event cancellation ${ }^{10}$ :

17. *Krenula je s pevanjem, ali nije zapevala.

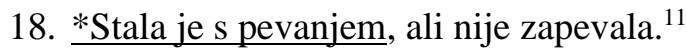

In terms of outer aspect on the level of syntax, Antonić (2000) concludes that in aspectual constructions, the aspectual value of the VP gets its identification from the (primary) phase verb. The aspectualizer also carries grammatical features which mark the VP as finite, such as person, number or tense. Antonić then goes on to state that the situation is somewhat different with modal verbs. Namely, unlike phase verbs, modal verbs are not restricted in terms of complementation, e.g. može/hoće da radi/uradi (Antonić, 2000: 97). Modal verbs as decomposed predicate heads are also as a rule imperfective: they only mark/modify possibility, volition etc. that is, they do not contribute the notion [+realized] to the constructional meaning. ${ }^{12}$ Finally, since secondary aspectual verbs in Serbian exhibit the behavior close to that of modal verbs, due to the fact that their lexical specification contains more than one potential meaning in the lexicon (cf. Milivojević 2021a, 2021b), that may be a plausible explanation for the instances of krenuti illustrated in the example (15). We now go on to take a closer look at the Aktionsart features of krenuti and stati, inside and outside of the aspectual construction.

\footnotetext{
${ }^{10}$ A full account of event-cancelling semantic operation is given in Milivojević, 2021c.

${ }^{11}$ In the example (18), a possible grammatical interpretation of the sentence would yield its lexical, not aspectual reading.

${ }^{12}$ Antonić points out that modal verb morati is different in this respect, since this verb may contribute the notion of past or future realization to the complement event.
} 


\section{AKTIONSART FEATURES OF SECONDARY ASPECTUAL VP}

In the present research, we propose the analysis along the lines of Hirtle (1988) where it is generally assumed that language "forms" have underlying meanings through which they entertain systematic relations with other forms in the system. This proposal also goes hand in hand with the number of other lexicalist, syntactic and constructional approaches which enhance the role of interpretation of contextualized constructions and/or propositions (cf. Aljović, 2000, 2015; Arad, 1998; Duffley, 1999; Goldberg 1995, 2009; Levin, 1993, 2000; Milivojević 2016, 2021a, 2021b, 2021c; Mourelatos, 1978; Perlmutter, 1970; Pustejovsky, 1995; Talmy, 1991, among others). The underlying, or potential meanings may be actualized in different ways in usage, where the resulting senses are then seen as actual meanings. (Hirtle 1988: 40) ${ }^{13}$

\subsection{Revisiting Vendler's V situation types}

In the light of lexical aspect, or Aktionsart, we adopt the theoretical point by Mourelato (1978) and Hirtle (1988:88) that the distinction between, for example, accomplishments and achievements ${ }^{14}$ should not be taken as reflecting types of verb lexeme or "hard and fast categories into which we can split verbs once and for all". Rather, situation types characterize how a particular verb is used in a given context to evoke a particular experience of the speaker. That is to say, this first lexical distinction shows "how the lexeme is like the matter of a verb which is variously moulded by the grammatical forms of the verb in view of the message to be expressed" (Hirtle,1988:88). So, the achievement/accomplishment distinction should not be viewed exclusively as an inherent characteristic of the lexical elements involved in a structure; we argue that those are in fact two ways of fitting the lexical import to the different grammatical frames provided by the event time. "In short, it is misleading to classify verbs according to these types; only uses in particular sentences can be so categorized." (Hirtle 1988: 88)

\footnotetext{
${ }^{13}$ Such an account also potentially provides an elegant means of dealing with the crucial problem of polysemy and so permits us to understand how a single morphological form can have several senses in discourse and yet still serve as an effective instrument for thought and communication.

${ }^{14}$ Our claim is that such an account covers all situation types proposed by Vendler, 1957, as well as the later theories based on Vendlerian situation types.
} 


\subsection{Lexical aspect and event structure of the secondary aspectual constructions} with krenuti and stati

Outside of the aspectual construction, krenuti and stati are semelfactive verbs. That is to say, they denote an event with minimal duration ${ }^{15}$ and lexicalize the opening/starting of the aspectual event. In turn, when these verbs are used as phase denoting lexemes, various authors (for example Duffley, 1999, 2006; Milivojević, 2021c; Nagy, 2009, 2016) talk about their additional lexical semantics, where they are marked for dynamicity and causality. In the light of this proposal, Palmer (2009: 22) also claims that it is possible for an aspectual verb to suggest not only a simple initiation of the situation (activity or state), but to suggest "initiation plus progressivity". Following Palmers's account, to the "simple" event initiation (associated with, for example, English verb begin and Serbian verb početi) we assign the aspectual features initiation + origination, whereas to English start and Sebian krenuti $^{16}$, we assign initiation + progressivity. Unlike krenuti, stati is marked as momentary, dynamic, and without [initiation + progressivity]. The described sets of aspectual features crucially influence the event structure of the aspectual construction as well as the way in which secondary aspectualizers krenuti and stati interact with the construction as a whole, giving rise to various contextually identifiable Aktionsarts:

19. a) Te ideje su još ranije krenule da postoje. (complement event: state)

b) Krenula je da plače. (complement event: activity)

c) Krenuo je da (iz)gradi/(iz)graditi kuću. (complement event: accomplishment)

d) Krenuli su da se dogovore. (complement event: accomplishment)

e) Krenula je da zaplače. (complement event: achievement)

f) Krenuo je da (po)skoči. (complement event: achievement)

20. a) *Te ideje su još ranije stale da postoje. (complement event: state)

b) Stala je da plače. (complement event: activity)

\footnotetext{
${ }^{15}$ As it was noted in previous discussion, we claim that every event denoted by a verb has to have feature [+duration]; with momentary verbs we speak of minimal duration, not of events with no duration.

${ }^{16}$ The contrastive account between English and Serbian in this respect has been elaborated in Milivojević 2021b.
} 
c) *Stali su da se dogovore. (complement event: accomplishment)

d) *Stala je da zaplače. (complement event: achievement)

e) Stao je da (*iz)gradi kuću. (complement event: accomplishment)

f) *Stao je da (po)skoči. (complement event: achievement)

As the examples (19a-f) show, secondary aspectual verb krenuti expresses a full possible range of both syntactic and situation types in the complement position, while stati is limited to activities (20b), that is, stati cannot combine with either states or telic situations.

On the level of the construction, (unlike with grammatical aspect explained in section (3) of the paper), in terms of lexical aspect the situation type is cocompositional, due to traces of other meanings/semantic conflations of the aspectual construction head. This also limits the range of potential aspectual complements which may or may not be available for combination with individual secondary aspectual verbs. The following examples $(21-24)$ (in line with the earlier examples $(10-14)$ in section (3)) from the corpus SrpKor, illustrate the use of aspectual krenuti with semelfactive complements, i.e. the event with minimal duration which cannot be segmented. These are extremely frequent with krenuti, but impossible with stati:

21. Desetak sekundi pre kraja Berić je krenuo da efektno potvrdi pobedu. Međutim, oštro je fauliran, posle čega je rukom udario Aškrabića idošlo je do tuče više igrača. (SrpKor 2013: Politika, 08.04.2001.)

22. A kad je voda počela da ključa i da se puši, Monmorensi je to smatrao izazovom. I baš kad bi krenuo da ga napadne, neko od nas bi mu ispred nosa odneo čajnik. (SrpKor 2013; Džerom K. Džerom, Tri čoveka u čamcu.)

23. U optužnici se navodi da je Plećić posle kraće prepirke ustao od stola i okrenut leđima prema optuženima krenuo da izvadi oružje, a tada su Drašković i Golubović ispalili po dva metka Plećiću u leđa. (SrpKor 2013; Politika, 24.02.2001.)

24. Nastavio je da laže, rekavši da u Sarajevu nije ni bio. Onda sam krenula da ga udavim golim rukama. Momci su ga jedva spasili iz mojih kandži. (SrpKor 2013: Svet, broj 211)

Achievements cannot be complements of stati, though semelfactives are best as prototypical complements to stati on the iterated interpretation. 
That is, stati requires its complement to have "true", marked duration which is longer than a minimal temporal segment, thus allowing only for minimal segment repetition, or the activity reading of the semelfactive event:

25. A i lepo je sada na Kljazmi - - stade da podbada prisutne Kolmilar Žorž... (SrpKor 2013: Bulgakov, Mihail Afanasjevič. Majstor $i$ Margarita. Beograd : Nolit, 1995.)

26. Latunski! Pa to je on! On koji je uništio majstora! Domar pokraj vrata izbeči oči i čak stade da podskakuje od čuđenja, sav upiljen u crnu tablu, u nastojanju da shvati to čudo. (SrpKor 2013: Bulgakov, Mihail Afanasjevič. Majstor i Margarita. Beograd : Nolit, 1995.)

The behavior of stati in the examples (25) and (26) is in accordance with the previous formal explanation of aspectual features of verbs which modify the nucleus of the aspectual event, not its onset: such verbs carry features initiation + origination, thus marking the beginning of the event, but do not have features initiation + progressivity, which is why the progressivity is required from the complement event, as any aspectual event by definition has to carry the aspectual feature [+ duration]. Under such conditions, the Aktionsart of the aspectual event on the level of the construction is co-compositional, as the necessary aspectual features are arrived at via interaction of the aspectual and complement event.

\section{CONCLUDING REMARKS}

The paper presents a detailed analysis of the aspectual features of two Serbian verbs krenuti and stati. The two analyzed verb lexemes belong to the subset of Serbian aspectual verbs, namely they are secondary or atypical aspectualizers which can be used both as lexical and as semantically incomplete verbs. Starting from the lexical level, the present analysis systematically explains the aspectual behavior of the two verbs both in terms of grammatical and lexical aspect, accounting for the differences in their "constructional" behavior. It was shown that lexical semantics of the secondary aspectual verb significantly determines its syntactic behavior. Also, while grammatical aspect of the construction is dominated by the aspectual features of the head verb(s), Aktionsart is for the most part compositional, i.e. the situation type of the construction is dynamic in character and can be properly identified only on the level of contextual usage. 
Nataša Milivojević

\title{
O ASPEKATSKOJ VREDNOSTI I AKCIONALNOSTI SEKUNDARNIH ASPEKTUALNIH GLAGOLA U SRPSKOM JEZIKU
}

\begin{abstract}
Sažetak
Rad se bavi analizom sekundarne aspektualne fraze u srpskom jeziku, u pogledu gramatičkog i leksičkog aspekta (akcionsarta ili akcionalnosti). Posmatra se aspektualna fraza koja na poziciji upravnog glagola sadrži sekundarne aspektualizatore krenuti i stati. Ova dva glagola imaju antonimna leksička značenja, međutim kada se koriste kao aspektulani glagoli, oni modifikuju isti, tj. početni, segment aspektualnog događaja. Ključna teorijska postavka kojom se rukovodimo u analizi jeste da tip glagolske situacije, tj. njegov akcionsart (up. Vendler 1957) suštinski zavisi od temporalne strukture glagolskog događaja koji je označen određenim glagolom. Povrh toga, jedino se kontekstualizovana temporalna struktura može identifikovati kao definisani tip situacije: drugim rečima, leksički aspekt nije inherentno svojstvo leksičkog značenja glagola, već se on realizuje, aktualizuje i ispoljava na nivou morfosintakse, u pripadajućem optimalnom kontekstu (up. Hirtle 1982). Značenja glagola krenuti i stati posmatraju se kako na nivou lekseme, tako i u okviru aspektualne konstrukcije. Definišu se aspektualna svojstva pojedinačnih glagola, a potom se određuje aspektualna vrednost konstrukcije u okviru koje se posmatrani glagoli javljaju na poziciji upravnog elementa. Pokazano je da leksičko značenje glagola utiče na potencijal koji taj glagol može ispoljiti kao aspektualizator, tačnije leksički koren glagola definiše kako leksički, tako i aspektualni identitet glagolske lekseme. Povrh toga, aspektualni modifikator i komplement stoje u odnosu sintaksičke ko-kompozicije, što je u skladu sa tvrdnjom da se potpuni identitet glagolskog događaja može odrediti samo ukoliko je značenje aktualizovano u kontekstu. Pokazano je da, u pogledu gramatičkog aspekta, aspektualna vrednost konstrukcije suštinski zavisi od upravnog elementa, dok se akcionalnost realizuje putem kokompozicije na leksičko-sintaksičkom i morfosintaksičkom nivou. Rezultati analize provereni su na Korpusu savremenog srpskog jezika Matematičkog fakulteta u Beogradu (SrpKor 2013).
\end{abstract}

Ključne reči: aspektualna fraza, akcionsart, aspektualni događaj, temporalna struktura, sekundarni aspektualizator, segmentacija događaja, ko-kompozicija 


\section{SOURCES}

SrpKor 2013: Vitas, Duško - Utvić, Miloš. „Korpus savremenog srpskog jezika (SrpKor), verzija SrpKor2013“. Grupa za jezičke tehnologije Univerziteta $\mathrm{u}$ Beogradu, Available online at http://www.korpus.matf.bg.ac.rs/korpus/ (Accessed: 1.7.2021).

Stevanović, M. -Marković, S. -Matić, S. -Pešikan, M. (ured.) (1967-1976). Rečnik Matice srpske I-VI: Rečnik srpskohrvatskoga književnog jezika. Novi Sad: Matica srpska, Zagreb: Matica hrvatska.

\section{REFERENCES}

Aljović, N. (2000). Unaccusativity and Aspect in Serbocroatian. Proceedings of CONSOLE 8, Leiden, Sole, $1-15$.

Aljović, N. (2015). Aspect of English Unnacusative Verbs", https://www.researchgate.net/publication/277717216_Aspect_of_English_ Unaccusative_Verbs [30.3.2021]

Antonić, I. (2000). Aspekatska vrednost predikacije s faznim/modalnim glagolom na primeru rečenice s temporalnom klauzom. Južnoslovenski filolog, 56 (12), 93-101.

Arad, M. (1998). Are unaccusatives aspectually characterized?. MIT Working Papers in Linguistic 32, 1-21.

Brinton, L. (1985). Verb Particles in English: Aspect or Aktionsart?", Studia Linguistica, 157-168.

Brinton, L. (1988). The Development of English Aspectual Systems. Cambridge: Cambridge University Press.

Comrie, B. (1976). Aspect: An Introduction to the Study of Verbal Aspect and Related Problems. Cambridge: Cambridge University Press.

Dowty, D. R. (1977). Toward a Semantic Analysis of Verb Aspect and the English 'Imperfective' Progressive. Linguistics and Philosophy, Vol. 1, Issue 1, 4577.

Duffley, P. J. (1999). The use of the infinitive and the -ing after verbs denoting the beginning, middle and end of an event. Folia Linguistica XXXIII/3-4, 295 331.

Duffley, P. J. (2006). The English gerund-participle in cognitive grammar. Columbia, SC: Hornbeam Press.

Freed, A. (1979). The Semantics of English Aspectual Complementation. Dordrecht: D. Reidel. 
Goldberg, A. (1995). Constructions: A Construction Grammar approach to argument structure. Chicago: Chicago University Press.

Goldberg, A. (2009). Constructions and Semantic Frames. In: Rappaport Hovav, M., E. Doron and I. Sichel (eds.). Syntax, Lexical Semantics and Event Structure. Oxford: Oxford University Press.

Harley, H. (1999). Denominal verbs and Aktionsart. In: L. Pylkanen and A. van Hout (eds.). Proceedings of the $2^{\text {nd }}$ Penn/MIT Rundatble on Event Structure, MITWPL: Cambridge, 73-85.

Harley, H. (2010). How do verbs get their names? Denominal verbs, manner incorporaton and the ontology of verb roots in English. In: Erteschik-Shir, Nomi and T. Rapoport (eds.). The Syntax of Aspect: Deriving Thematic and Aspectual Interpretation, Oxford Scholarship Online. DOI:10.1093/acprof:oso/9780199280445.003.0003

Hirtle, W. H. (1988). Events, Time and the Simple Form. Revue québécoise de linguistique, 17(1), 85-105. https://doi.org/10.7202/602615ar

Ivić, M. (1961). O pojavama sintaksičke obaveznosti. Godišnjak Filozofskog fakulteta u Novom Sadu, knjiga VI, 180-190.

Ivić, M. (1983). Lingvistički ogledi. Beograd: Prosveta.

Levin, B. (1993). English Verb Classes and Alternations: A Preliminary Investigation. Chicago: The University of Chicago Press.

Levin, B. (2000). Aspect, Lexical Semantic Representation, and Argument Expression. BLS 26: General Session and Parasession on Aspect, 413-429.

Milivojević N. (2016). Konstrukcioni idiomi u engleskom $i$ srpskom jeziku. Edisertacija10. Novi Sad: Filozofski fakultet. http://digitalna.ff.uns.ac.rs/ sadrzaj/2016/978-86-6065-384-2

Milivojević N. (2021a). O analitičkim predikatima sa glaglom krenuti u srpskom jeziku: leksičko-projekcionistički pristup. Srpski jezik, studije srpske $i$ slovenske,26 (I), Naučno društvo za negovanje i proučavanje srpskog jezika, Beograd, 193-216.

Milivojević N. (2021b). A contrastive account of phase verbs begin and start in English and Serbian. Nasleđe, 21 $1^{\text {st }}$ Century English: Theoretical and Applied Perspectives, 48, 203-218.

Milivojević N. (2021c). The event-cancelling semantics of the English aspectualizer start and its Serbian equivalent krenuti. Godišnjak filozofskog fakulteta $u$ Novom Sadu, knjiga XLVI-1, 31-46. 
Mrazović, P.-Vukadinović, Z. (1990). Gramatika srpskog jezika za strance. Sremski Karlovci, Novi Sad: Izdavačka knjižarnica Zorana Stojanovića, Dobra vest.

Mourelatos, A.P.D. (1978). Events, Processes and States. Linguistics and Philosophy 2, 415-434.

Nagy, T. (2009). The Semantics of Aspectualizers in English. (PhD dissertation), Debrecen University

Nagy, T. (2016). On Aspectualizers in English: A Corpus Based Approach. ClujNapoca: Scientia Publishing House.

Newmeyer, F., J. (1975). English Aspectual Verbs. The Hague: Mouton.

Palmer, F., R. (2009). Lexical Aspect in English. Selected Papers from the 18th ISTAL. https://www.enl.auth.gr/symposium18/papers/3_PALMER.pdf

Perlmutter, D., M. (1970). The two verbs begin. In: Jacobs R., A. and Rosenbaum P., S. (eds.), Readings in English Transformational Grammar. Waltham, MA: Ginn.107-119.

Piper, P.-Antonić, I.-Ružić, V.-Tanasić, S.-Popović, Lj.\&Tošović, B. (2005). Sintaksa savremenoga srpskog jezika, Prosta rečenica. Beograd: Institut za srpski jezik SANU.

Pustejovsky, J. (1995). The Generative Lexicon. Cambridge, MA: MIT Press.

Rothstein, S. (2004). Structuring Events, Oxford: Blackwell.

Talmy, L. (1991). Path to realization - via aspect and result, Proceedings of BLS 17, 480-519.

Vendler, Z. (1957). Verbs and Times. The Philosophical Review, 66, 143-160. 